\title{
PENGARUH PENERAPAN STRATEGI PEMBELAJARAN KOLABORATIF FISHBOWL TERHADAP KEMAMPUAN PEMECAHAN MASALAH MATEMATIKA SISWA KELAS VII SMP NEGERI 6 RENGAT
}

\author{
Sri Yunita Ningsih ${ }^{1}$, Nurseha $^{2}$ \\ ${ }^{1}$ Dosen Program Studi Matematika STKIP Insan Madani Airmolek \\ ${ }^{2}$ Mahasiswa Program Studi Matematika STKIP Insan Madani Airmolek \\ sriyunitaningsih89@gmail.com ${ }^{1}$
}

\begin{abstract}
The research is motivated by the low ability of problem solving in student math SMP Negeri 6 Rengat, the activity of students in following the lesson is still relatively low. The us of fishbowl collaborative learning strategy is throught to be able overcome the problem solving ability of student math which is still low. The purpose of this research is to know the ability of problem solving of student mathematics by using fishbowl collaborative learning strategy. This type of research is experimental research. The research design used was randomized subjects posttest only control group design. The population in these villages is class VII. The class selected to be the experimental class is the class VIIA and the control class is the class VIIB. The data collection technique used in this research is the ability problem solving test in the form of essay. Data analysis techniques in this test use $t$ test based on hypothesis test results obtained $t$ count $=-4,321$ and $\mathrm{t}$ table $=-2,010$. Based on hypothesis test results $\mathrm{t}$ arithmetic $<\mathrm{t}$ table with the real level used is 0,05 . Ho rejected. So, it can be concluded that the ability to solve mathematical problem with the application of fishbowl collaborative learning strategy is better than the ability to solve mathematical problems with the application of conventional learning strategies in the class VII SMP Negeri 6 Rengat.
\end{abstract}

Keywords: Collaborative Learning Strategy Fishbowl, Problem Solving

\begin{abstract}
Abstrak. Latar belakang masalah dalam penelitian ini adalah rendahnya kemampuan pemecahan masalah matematika siswa di SMP Negeri 6 Rengat, keaktifan siswa dalam mengikuti pelajaran masih tergolong rendah. Penggunaan Strategi Pembelajaran Kolaboratif Fishbowl diduga dapat mengatasi kemampuan pemecahan masalah matematika siswa yang masih rendah. Tujuan penelitian ini adalah untuk mengetahui kemampuan pemecahan masalah matematika siswa dengan menggunakan Strategi Pembelajaran Kolaboratif Fishbowl. Jenis penelitian ini adalah penelitian eksperimen. Rancangan penelitian yang digunakan adalah Randomized Subjects Posttest Only Control Group Design. Populasi pada penelitian ini adalah kelas VII. Kelas yang terpilih menjadi kelas eksperimen adalah kelas $\mathrm{VII}^{\mathrm{A}}$ dan kelas kontrol adalah kelas $\mathrm{VII}^{\mathrm{B}}$. Berdasarkan hasil uji hipotesis diperoleh nilai $t_{\text {hitung }}=-4,321$ dan $t_{\text {tabel }}=-2,010$. Berdasarkan hasil uji hipotesis $t_{\text {hitung }}<t_{\text {tabel }}$ dengan taraf nyata yang dipakai adalah 0,05 maka $\mathrm{H}_{\mathrm{o}}$ ditolak. Jadi, dapat disimpulkan bahwa kemampuan pemecahan masalah matematika dengan penerapan Strategi Pembelajaran Kolaboratif Fishbowl lebih baik dari pada kemampuan pemecahan masalah matematika dengan penerapan Strategi Pembelajaran Konvensional pada kelas VII di SMP Negeri 6 Rengat.
\end{abstract}

Kata Kunci: Strategi Pembelajaran Kolaboratif Fishbowl, Pemecahan Masalah

\section{PENDAHULUAN}

Pendidikan adalah salah satu bentuk perwujudan kebudayaan manusia yang dinamis dan sarat perkembangan. Perubahan atau perkembangan pendidikan adalah hal yang memang seharusnya terjadi sejalan dengan perubahan budaya kehidupan. Perubahan dalam arti perbaikan pendidikan pada semua tingkat perlu terus menerus dilakukan sebagai antisipasi kepentingan masa depan. Pendidikan adalah suatu proses dalam rangka mempengaruhi peserta didik supaya mampu menyesuaikan diri sebaik 
mungkin dengan lingkungannya, dan dengan demikian akan menimbulkan perubahan dalam dirinya yang memungkinkanya untuk berfungsi secara adekwat dalam kehidupan masyarakat.

Matematika adalah cara atau metode berpikir dan bernalar dengan bahasa lambang yang dapat dipahami oleh semua bangsa berbudaya. Menurut Hans Freudental, "matematika merupakan aktivitas insani yang harus dikaitkan dengan realitas". Dengan demikian, matematika merupakan cara berpikir logis yang dipresentasikan dalam bilangan, ruang, dan bentuk dengan aturan-aturan yang telah ada yang tak lepas dari aktivitas insani tersebut. Hamzah (2014) mengemukakan bahwa hakikat matematika adalah ilmu yang membahas angka-angka dan perhitungan.

Siagian (2017) menjelaskan bahwa Matematika tumbuh dan berkembang untuk dirinya sendiri sebagai suatu ilmu, juga untuk melayani kebutuhan ilmu pengetahuan dalam pengembangan operasionalnya. Melihat peran penting matematika dalam perkembangan ilmu pengetahuan dan tekmologi maka sudah seharusnya matematika disampaikan dengan cara yang menarik, yang dapat menarik minat dan perhatian siswa dalam proses penyampaian matematika. Oleh sebab itu sebagai seorang pendidik yang memiliki kewajiban dalam menyampaikan pembelajaran matematika kepada siswa harus dapat memperhatikan cara-cara yang baik, inovatif dan kreatif.

Pembelajaran matematika adalah suatu proses belajar mengajar yang dibangun oleh guru untuk mengembangkan kreatifitas berpikir yang dapat meningkatkan kemampuan berpikir siswa, serta dapat meningkatkan pengetahuan baru sebagai upaya meningkatkan penguasaan yang baik terhadap materi matematika. Dalam hal ini yang menjadi permasalahan adalah kurangnya kemampuan pemecahan masalah dalam pembelajaran matematika. Dapat dilihat dari observasi yang dilakukan oleh peneliti. Terlihat pada rata-rata hasil tes awal kemampuan pemecahan masalah matematika siswa dapat dilihat pada tabel 1 berikut:

Tabel 1.Hasil Rata-Rata Tes Awal Kemampuan Pemecahan Masalah Matematika Siswa SMP Negeri 6 Rengat

\begin{tabular}{cccc}
\hline No & Kelas & Banyak Siswa & Rata-Rata Tes Awal \\
\hline 1 & VII $^{\mathrm{A}}$ & 27 & 46,4815 \\
\hline 2 & VII $^{\mathrm{B}}$ & 24 & 48,625 \\
\hline
\end{tabular}

Berdasarkan pengamatan yang dilakukan di SMP Negeri 6 Rengat, Siswa kurang aktif dalam proses pembelajaran. Misalnya: siswa bercerita sendiri saat guru menerangkan materi, bercanda dengan teman sebangku. Hal ini disebabkan karena saat menjelaskan guru hanya menghadap kepapan tulis dan kurangnya interaksi antara guru dan siswa karena pembelajaran hanya fokus pada penjelasan guru saja, Siswa kurang mampu dalam memecahkan masalah terhadap persoalan yang diberikan, terlihat ketika guru memberikan soal banyak siswa yang tidak bisa menjawabnya. Hal ini disebabkan karena siswa jarang mengerjakan soal dalam bentuk pemecahan masalah. Sehingga kemampuan pemecahan masalah matematika siswa rendah, Kurangnya minat dan motivasi siswa dalam belajar matematika, dan kurangnya kemampuan dalam memecahkan masalah terhadap persoalan yang diberikan oleh guru. Hal ini disebabkan karena dalam proses pembelajaran masih menggunakan metode ceramah.

Kemampuan pemecahan masalah merupakan salah satu aspek dari tujuan pembelajaran matematika. Dalam standar isi pada Permendiknas No. 22 Tahun 2006 dinyatakan bahwa kemampuan memecahkan masalah matematika yang meliputi 
kemampuan memahami masalah, merancang model matematika, menyelesaikan model, dan menafsirkan solusi yang diperoleh adalah salah satu dari tujuan mata pelajaran matematika.

Menurut NCTM (2000:209) indikator-indikator untuk mengukur kemampuan pemecahan masalah matematika siswa meliputi: 1) Siswa dapat mengidentifikasi unsur-unsur yang diketahui, yang ditanyakan, dan kecukupan unsur yang diperlukan, 2) Siswa dapat merumuskan masalah matematik atau menyusun model matematik, 3) Siswa dapat menerapkan strategi untuk menyelesaikan berbagai masalah (sejenis dan masalah baru) dalam atau diluar matematika, 4) Siswa dapat menjelaskan hasil sesuai permasalahan asal, dan 5) Siswa dapat menggunakan matematika secara bermakna. Kemampuan pemecahan masalah matematika dalam penelitian ini adalah kemampuan siswa dalam menyelesaikan soal matematika berdasarkan langkah-langkah Polya. Adapun langkah pemecahan masalah menurut Polya (1973:xvi), yaitu: 1) Memahami masalah (understanding the problem), 2) Merancang rencana penyelesaian (devising a plan), 3) Melaksanakan rencana penyelesaian (carrying out the plan), dan 4) Melihat kembali langkah penyelesaian (looking back).

Salah satu upaya yang dapat dilakukan untuk memperbaiki kemampuan pemecahan masalah matematika siswa dengan menerapkan pembelajaran kolaboratif fishbowl. Metode Fishbowl merupakan metode berdiskusi yang menggunakan format lingkaran. Sebagian siswa membentuk lingkaran diskusi dan siswa-siswa yang lain membentuk lingkaran pendengar di sekeliling kelompok diskusi. Metode Fishbowl sangat tepat untuk meningkatkan perhatian siswa dan mengembangkan kemampuan berdiskusi.

\section{METODE}

Penelitian ini menggunakan Quasi Experimental Design. Jenis penelitian ini digunakan karena merupakan pengembangan dari true experimental design, yang yang sulit dilaksanakan. Desain ini mempunyai kelompok kontrol, tetapi tidak dapat berfungsi sepenuhnya untuk mengontrol variabel-variabel luar yang mempengaruhi pelaksanaan eksperimen. Rancangan penelitian yang digunakan adalah Randomized Subjects Posttest Only Control Group Design.

Tabel 2. Bentuk Randomized Subjects Postest Only Control Group Design

\begin{tabular}{llcc}
\hline & \multicolumn{1}{c}{ Group } & Variabel terikat & Post-Test \\
\hline $\mathrm{R}$ & Eksperimen & $\mathrm{X}$ & $\mathrm{Y}_{2}$ \\
\hline $\mathrm{R}$ & Kontrol & & $\mathrm{Y}_{2}$ \\
\hline
\end{tabular}

Keterangan:

$\mathrm{R}=$ Randomisasi

$\mathrm{X}=$ Kelompok yang diberikan perlakuan (treatmeant)

$\mathrm{Y}_{2}=$ Posttest

Adapun sampel dalam penelitian ini yaitu semua populasi dijadikan sebagai objek penelitian (sampel total). Yang mana kelas $\mathrm{VII}^{\mathrm{A}}$ sebagai kelas eksperimen dan kelas $\mathrm{VII}^{\mathrm{B}}$ sebagai kelas kontrol. Instrumen penelitian pada penelitian ini berupa tes kemampuan pemecahan masalah matematika siswa yang dilaksanakan diakhir penelitian. Penerapan strategi pembelajaran pencapaian pemecahan masalah dalam 
penelitian ini membutuhkan data-data yang dapat dianalisis sehingga dapat ditarik kesimpulan yang akurat dari hasil eksperimen yang dilakukan. Adapun teknik pengumpulan data dalam penelitian ini berupa observasi, tes dan dokumentasi. Instrument penelitian ini adalah tes uraian tertulis. Teknis analisis data yang digunakan sudah jelas, yaitu diarahkan untuk menjawab rumusan masalah atau menguji hipotesis yang telah dirumuskan dalam penelitian. Sebelum uji hipotesis dilakukan, maka terlebih dahulu dilakukan uji normalitas dan uji homogenitas variansi kedua kelompok data.

\section{HASIL DAN PEMBAHASAN \\ Hasil}

Pengumpulan data mengenai hasil kemampuan pemecahan masalah matematika siswa dengan menggunakan tes akhir (posttest). Tes diberikan kepada kedua kelas sampel. Soal yang diberikan berbentuk uraian sebanyak 4 butir dengan alokasi waktu 80 menit. Tes akhir ini diikuti sebanyak 51 orang siswa, 27 orang kelas eksperimen dan 24 orang kelas kontrol.Kemampuan pemecahan masalah matematika siswa diperoleh dari hasil perhitungan secara statistik, sehingga diperoleh nilai rata-rata $(\bar{x})$, simpangan baku (s) dan variansi $\left(s^{2}\right)$ dari kedua kelas sampel yang dinyatakan pada tabel berikut.

Tabel 3. Hasil Perhitungan Data Kemampuan Pemecahan masalah

\begin{tabular}{lcccc}
\hline \multicolumn{1}{c}{ Kelas } & $\widetilde{\boldsymbol{x}}$ & $\boldsymbol{N}$ & $\mathbf{S}$ & $\mathbf{s}^{\mathbf{2}}$ \\
\hline Eksperimen & 79,592 & 27 & 40,405 & 6,356 \\
\hline Kontrol & 74,25 & 24 & 47,674 & 6,905 \\
\hline
\end{tabular}

Dari Tabel di atas, terlihat bahwa nilai rata-rata kemampuan pemecahan masalah matematika siswa kelas eksperimen 79,592 dan kelas kontrol 74,25. Ini menunjukkan bahwa kelas eksperimen lebih baik dari kelas kontrol. Disamping itu, standar deviasi kelas eksperimen lebih kecil daripada kelas kontrol. Ini menunjukkan bahwa hasil belajar kelas eksperimen lebih homogen dan tidak terdapat perbedaan yang sangat jauh antara kelas atas (anak yang pintar) dengan kelas bawah (anak yang kurang pintar) bila dibandingkan dengan kelas kontrol.

\section{Analisa Data}

Untuk menarik kesimpulan dari hasil penelitian yang dilakukan, maka data yang diperoleh dari tes kemampuan pemecahan masalah matematika siswa dilakukan analisis data secara statistik yaitu uji hipotesis dengan uji Uji Independent Samples TTest atau uji t. Sebelum dilakukan uji $t$ terlebih dahulu penulis melakukan uji normalitas dan homogenitas.

a. Uji normalitas

Uji normalitas dilakukan dengan cara Uji Liliefors. Uji Liliefors dilakukan bertujuan untuk melihat apakah sampel berdistribusi normal atau tidak. Uji ini dilakukan kepada kedua kelas sampel yaitu kelas eksperimen dan kelas kontrol dengan taraf kepercayaan 95\%. Uji normalitas pada penelitian ini dilakukan dengan menggunakan software SPSS 15.0. Hasil Perhitungan uji normalitas kedua sampel dapat dilihat pada tabel berikut. 
Tabel 4. Hasil Perhitungan Uji Normalitas Kelas Sampel Kemampuan Pemecahan Masalah Matematika Siswa

\begin{tabular}{lccc}
\hline \multicolumn{1}{c}{ Sampel } & Nilai Sig. & Nilai $\boldsymbol{\alpha}$ & Keterangan \\
\hline Eksperimen & 0,210 & 0,05 & Normal \\
\hline Kontrol & 0,277 & 0,05 & Normal \\
\hline
\end{tabular}

Dari tabel terlihat bahwa pada kelas eksperimen nilai Signifikan adalah 0,210 dan nilai signifikan untuk kelas kontrol adalah 0,277 karena nilai signifikan pada kedua kelas lebih besar dari $\alpha=0,05$ maka dapat disimpulkan bahwa kedua sampel berdistribusi normal.

b. Uji homogenitas

Selain data berasal dari sampel yang terdistribusi normal, harus diperhatikan juga apakah kedua sampel homogen atau tidak. Maka dari itu dilakukan uji homogenitas. Harga $F_{\text {hitung }}$ dan $F_{\text {tabel }}$ dari tes kemampuan pemecahan masalah matematika siswa pada taraf nyata 0,05 dapat dilihat pada Tabel 5 di bawah ini.

Tabel 5. Harga $F_{\text {hitung }}$ Dan $F_{\text {tabel }}$ Tes Kemampuan Pemecahan Masalah Matematika

\begin{tabular}{ccc}
\hline & \multicolumn{2}{c}{ Kelas } \\
\cline { 2 - 3 } & Eksperimen & Kontrol \\
\hline $\mathbf{N}$ & 27 & 24 \\
\hline $\mathbf{S}^{\mathbf{2}}$ & 60,567 & 67,125 \\
\hline $\boldsymbol{F}_{\text {hitung }}$ & \multicolumn{3}{c}{0,85} \\
\hline $\boldsymbol{F}_{\text {tabel }}$ & \multicolumn{2}{c}{1,13} \\
\hline Keterangan & \multicolumn{2}{c}{ Homogen } \\
\hline
\end{tabular}

Dari Tabel terlihat bahwa $F_{\text {hitung }}<F_{\text {tabel }}$, artinya kedua kelas mempunyai variansi yang homogen

c. Uji hipotesis

Setelah pengujian normalitas dan homogen diperoleh hasil bahwa kedua sampel berdistribusi normal dan mempunyai variansi homogen, maka dilakukan uji hipotesis dengan menggunakan (Uji $t$ ) Independent Samples T-Test dengan bantuan software SPSS. Berdasarkan hasil uji $t$ tersebut, diperoleh nilai thitung $=-4,321$ dan didapat $t_{\text {tabel }}$ $=-2,010$ dengan (df) $\mathrm{n}-2$ dan taraf nyata $5 \%$. Karena nilai $\mathrm{t}_{\text {hitung }}=-4,321<\mathrm{t}_{\text {tabel }}=-$ 2,010, sehingga $t_{\text {hitung }}$ berada didaerah penolakan $\mathrm{H}_{0}$ sehingga dapat disimpulkan bahwa hipotesis nol $\left(\mathrm{H}_{0}\right)$ ditolak dan hipotesis alternatif $(\mathrm{Ha})$ diterima. Dengan demikian hipotesis yang diajukan dalam penelitian ini diterima yaitu "Kemampuan Pemecahan Masalah Matematika Siswa dengan menggunakan Strategi Pembelajaran kolaboratif fishbowl lebih baik dari pada Kemampuan Pemecahan Masalah Matematika Siswa dengan menggunakan Pembelajaran Konvensional pada kelas VII SMP Negeri 6 Rengat".

\section{Pembahasan}

Berdasarkan hasil penelitian yang telah dilakukan, kemampuan pemecahan masalah matematika siswa yang di ajar dengan strategi pembelajaran Kolaboratif Fishbowl lebih baik daripada kemampuan pemecahan masalah matematika yang diajar dengan pembelajaran konvensional. Hal ini dikarenakan pada tahap penggunaan strategi pembelajaran Kolaboratif Fishbowl siswa dilatih untuk menyelesaikan permasalahan matematika dalam dunia nyata ke dalam bahasa matematika atau siswa 
dilatih untuk dapat menyelesaikan permasalahan matematika yang berkaitan dengan kehidupan sehari-hari.

Berikut ini disajikan deskripsi dari bentuk-bentuk indikator kemampuan pemecahan masalah siswa pada kelas eksperimen dan kelas kontrol yang diperoleh dari hasil tes kemampuan pemecahan masalah matematika siswa.

\section{1). Mengidentifikasi unsur yang diketahui dan membuat model matematika.}

Kemampuan mengidentifikasi unsur yang diketahui pada kelas eksperimen dan kelas kontrol ditinjau dari hasil tes kemampuan pemecahan masalah matematika siswa pada soal nomor 1 berikut ini.

Sebuah rumah memiliki bagian atap yang berbentuk segitiga sama kaki. Yang mana panjang dua buah sisinya adalah $10 \mathrm{~cm}$ dan $4 \mathrm{~cm}$, dan besar salah satu sudutnya adalah $66^{\circ}$.

Siswa diminta untuk mencari besar sudut lainnya dan panjang sisi lainnya. Jawaban soal nomor 1 pada kelas eksperimen dapat dilihat pada gambar 2 di bawah ini.

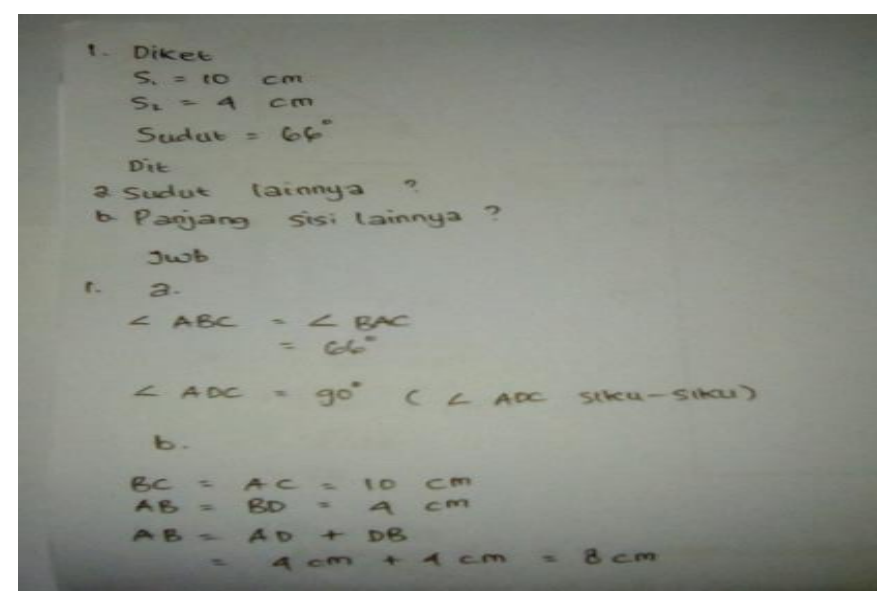

Gambar 1. Jawaban Soal Nomor 1 Kelas Eksperimen

Dan jawaban pada kelas kontrol dilihat pada gambar 2 berikut.

Gambar 2. Jawaban Soal Nomor 1 Kelas Kontrol

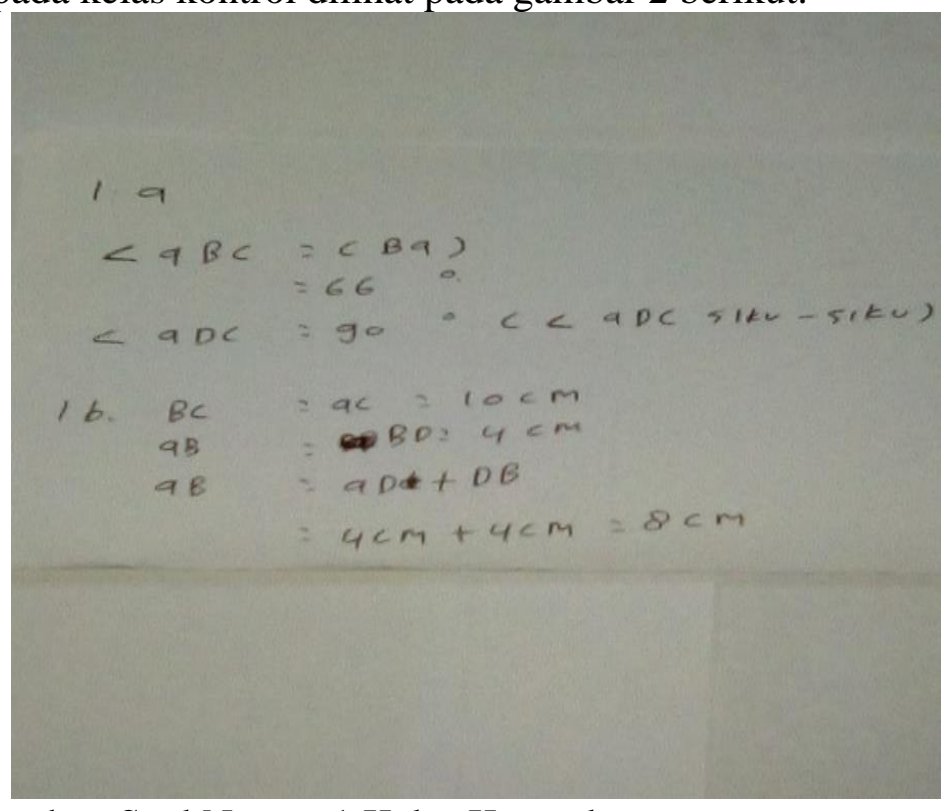


2) Melaksanakan rencana pemecahan masalah menerapkan startegi menyelesaikan masalah, menyelesaikan model matematika dan masalah nyata, serta menggunakan matematika secara bermakna.

Kemampuan Melaksanakan rencana pemecahan masalah menerapkan startegi menyelesaikan masalah, menyelesaikan model matematika dan masalah nyata, serta menggunakan matematika secara bermakna pada kelas eksperimen ditinjau dari hasil tes kemampuan pemecahan masalah matematika siswa pada soal nomor 3 dan 4 seperti berikut.

Perhatikan gambar di bawah ini!

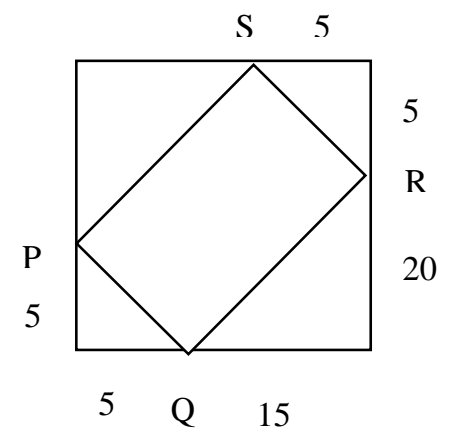

Gambar di atas menunjukkan sebidang tanah berukuran $20 \mathrm{~m} \times 25 \mathrm{~m}$, yang di dalamnya ditanami rumput berbentuk segi empat PQRS. Jika biaya penanaman rumput per $\mathrm{m}^{2} \mathrm{Rp} 20.000$, tentukan besar biaya penanaman rumput tersebut!

Jawaban dari soal nomor 3 tersebut pada kelas sampel, diambil dari perwakilan siswa pada kelas eksperimen dan kontrol. Jawaban siswa pada kelas eksperimen dapat dilihat pada Gambar 3 berikut.

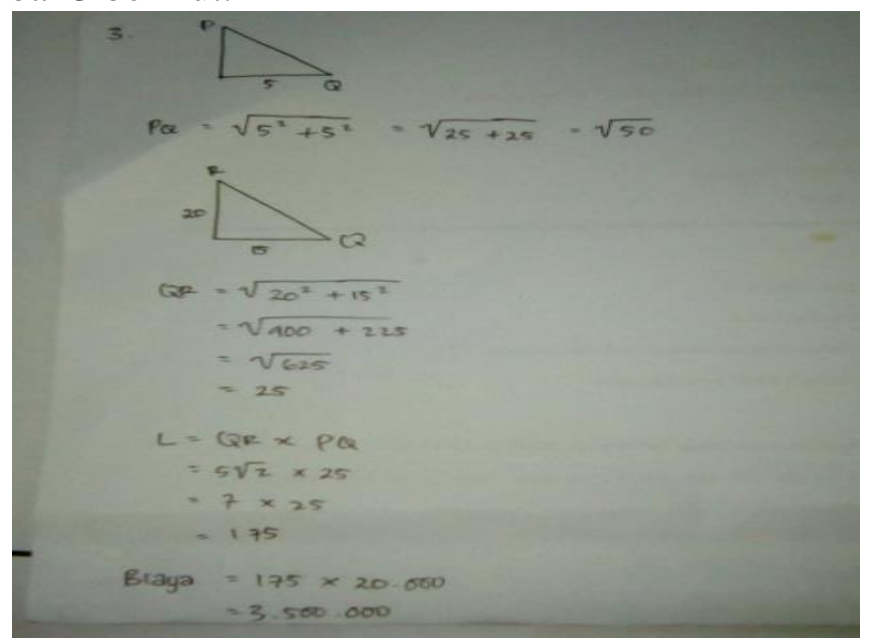

Gambar 3. Jawaban Soal Nomor 3 Kelas Eksperimen

Sedangkan jawaban siswa pada kelas kontrol dalam menjawab soal nomor 3 dapat dilihat pada Gambar 4 berikut. 


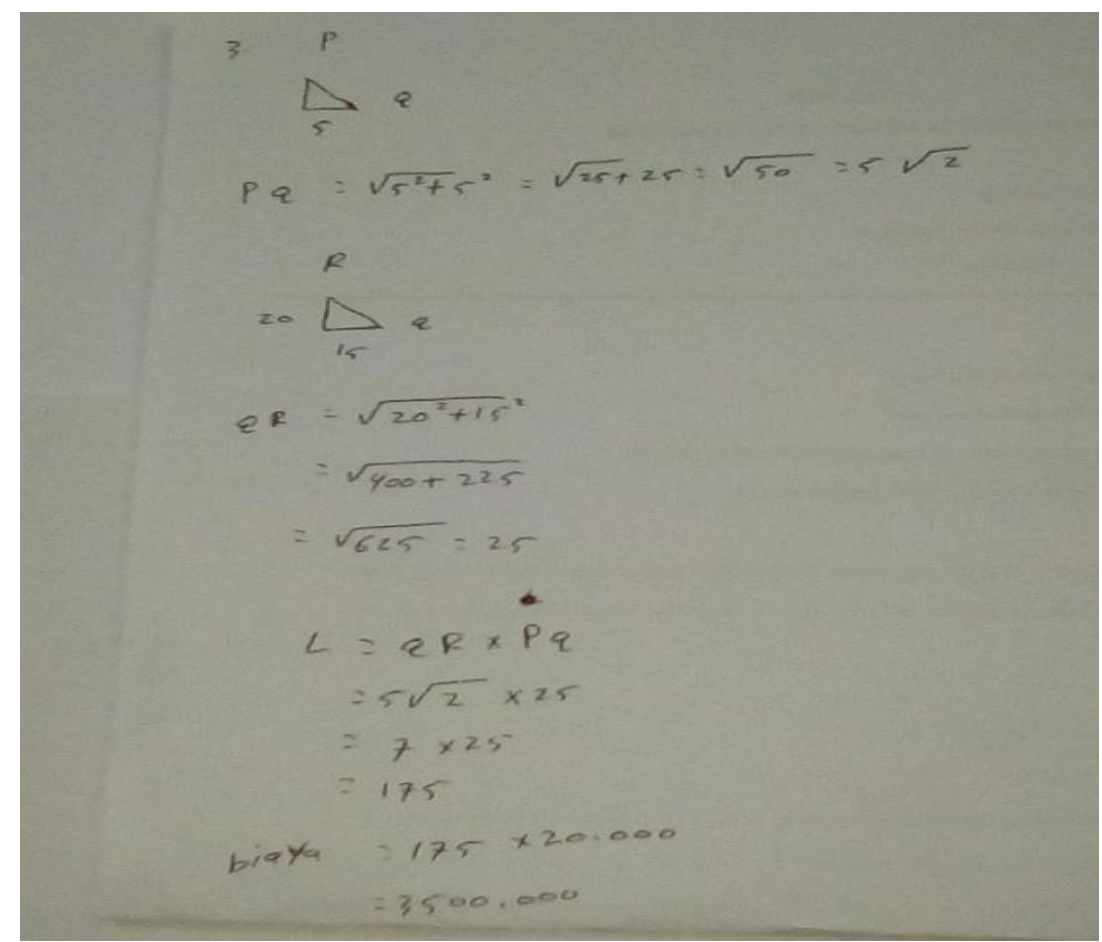

\section{Gambar 4. Jawaban Soal Nomor 3 Kelas Kontrol}

Sedangkan untuk soal nomor 4 yaitu: Sebidang tanah berbentuk segitiga dengan panjang tiap sisi tanah berturut-turut $4 \mathrm{~m}, 5 \mathrm{~m}$, dan $7 \mathrm{~m}$. Di sekeliling tanah tersebut akan dipasang pagar dengan biaya Rp $85.000,00$ per meter. Berapakah biaya yang diperlukan untuk pemasangan pagar tersebut?

Jawaban dari soal nomor 4 tersebut pada kelas sampel, diambil dari perwakilan siswa pada kelas eksperimen dan kontrol. Jawaban siswa pada kelas eksperimen dapat dilihat pada Gambar 5 berikut.

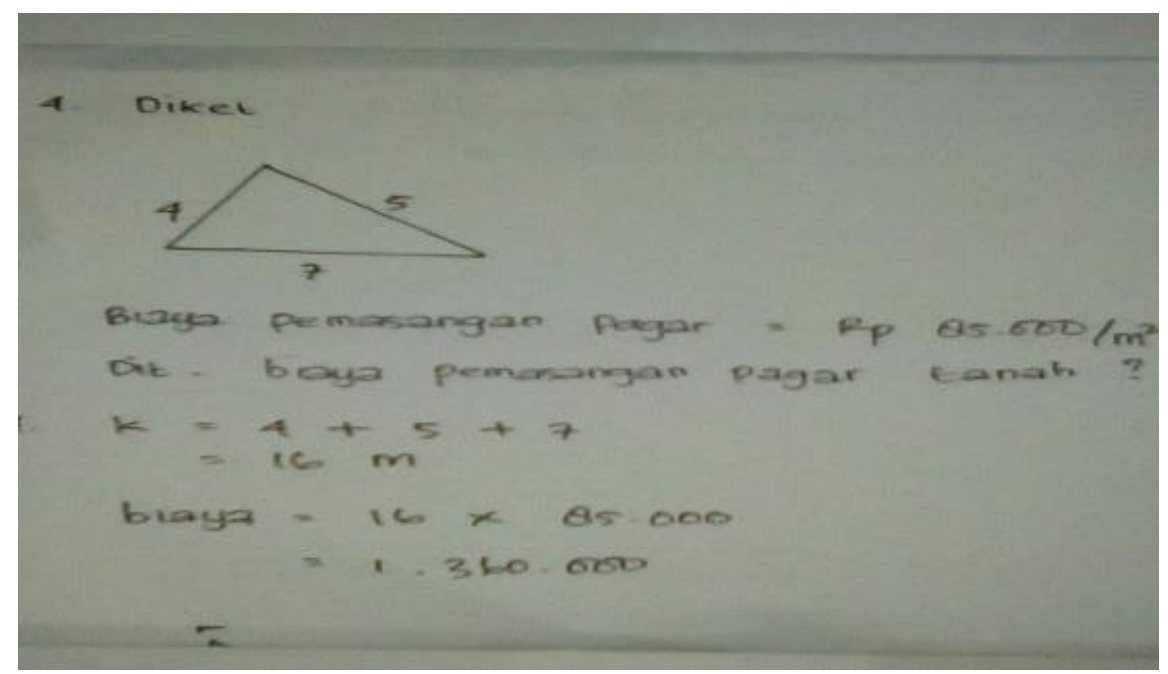

Gambar 5. Jawaban Soal Nomor 4 Siswa Kelas Eksperimen

Sedangkan jawaban siswa pada kelas kontrol dalam menjawab soal nomor 4 dapat dilihat pada Gambar 6 berikut. 


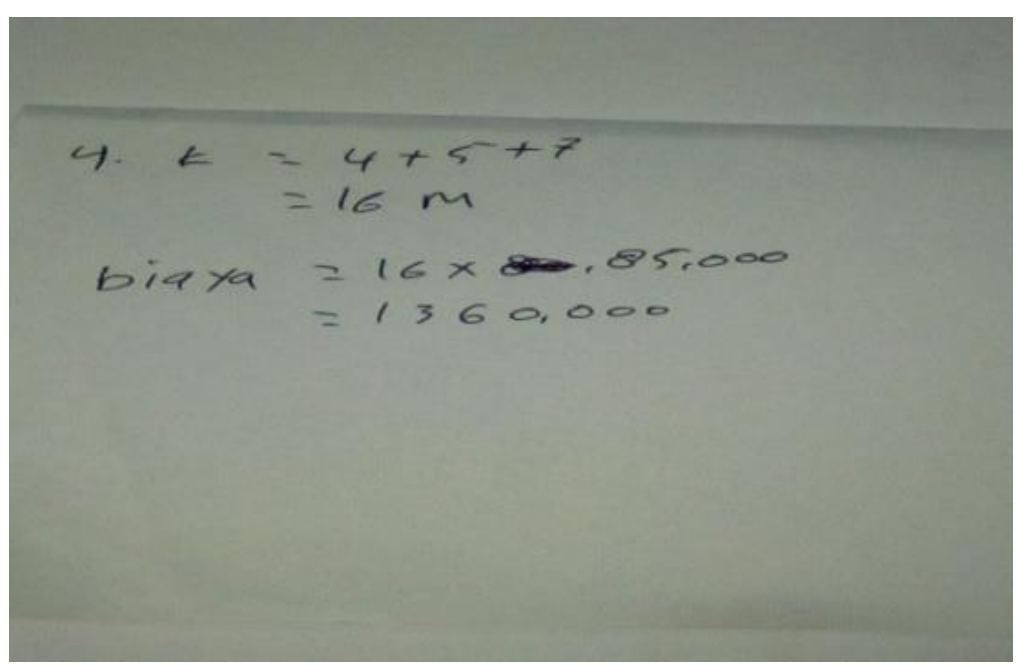

Gambar 6. Jawaban Soal Nomor 4 Siswa Kelas Kontrol

\section{3) Menjelaskan menginterprestasikan hasil}

Kemampuan menjelaskan / meninterprestasikan hasil pada kelas eksperimen ditinjau dari hasil tes kemampuan pemecahan masalah matematika siswa pada soal nomor 2 berikut ini.

Sebuah taman berbentuk segitiga sama kaki dengan panjang sisi yang sama 15 $\mathrm{m}$, panjang sisi lainnya $12 \mathrm{~m}$, dan tinggi $7 \mathrm{~m}$. Jika taman tersebut akan ditanami rumput dengan biaya $\mathrm{Rp} .60 .000 / \mathrm{m}^{2}$, hitunglah keseluruhan biaya yang diperlukan?

Jawaban dari soal nomor 2 tersebut pada kelas sampel, diambil dari perwakilan siswa pada kelas eksperimen dan kontrol. Jawaban siswa pada kelas eksperimen dapat dilihat pada Gambar 7 di bawah ini.

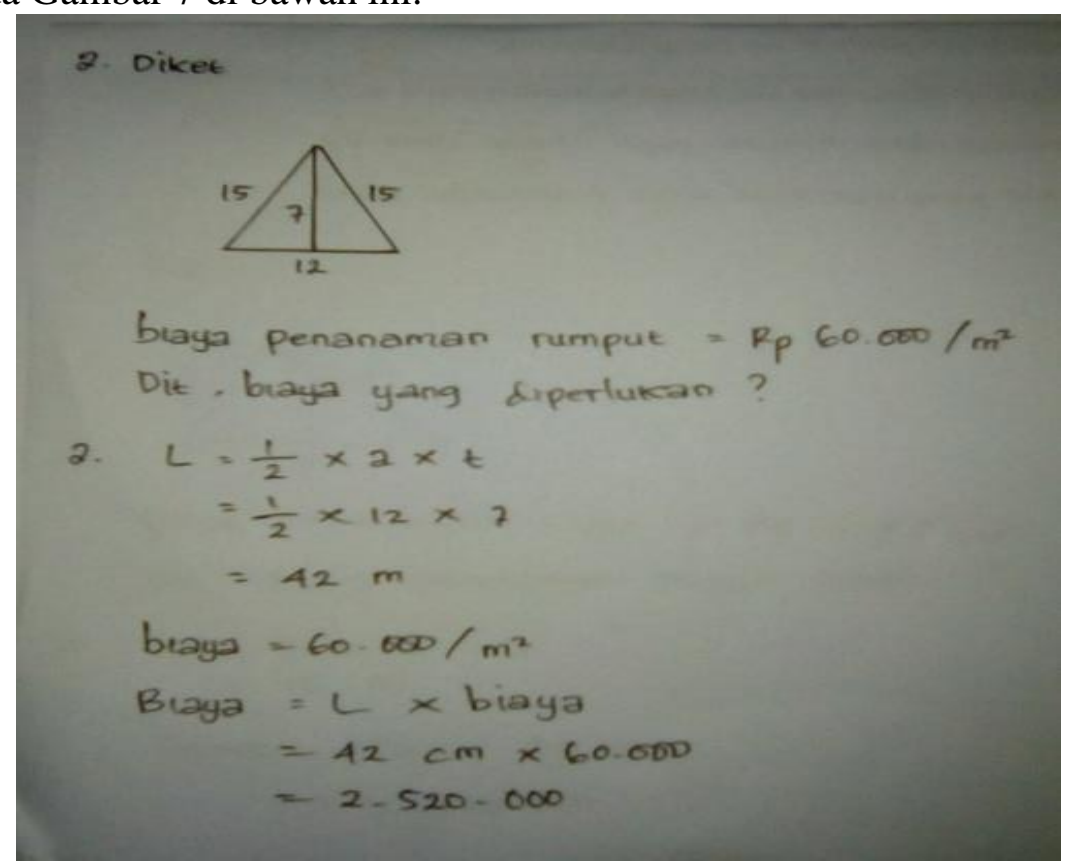

Gambar 7. Jawaban Soal Nomor 2 Siswa Kelas Eksperimen

Sedangkan jawaban dari soal nomor 2 pada siswa kelas kontrol dapat dilihat pada Gambar 8 di bawah ini. 


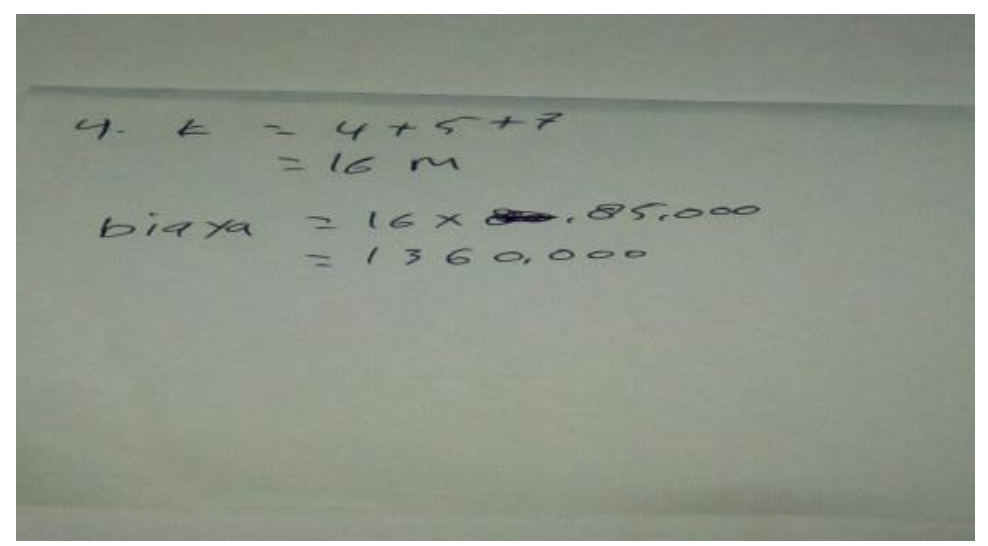

\section{Gambar 8. Jawaban Soal Nomor 2 Siswa Kelas Kontrol}

Perbedaan kemampuan menjelaskan/menginterprestasikan hasil pada kelas eksperiemen dan kontrol dipengaruhi oleh proses pembelajarannya. Pada kelas eksperimen terdapat kegiatan pembelajaran yang menggunakan LKS, dimana siswa dilatih menyelesaikan soal-soal yang berkaitan dengan permasalahan di dalam kehidupan sehari-hari pada LKS tersebut, kemudian dipresentasikan sedangkan pada kelas kontrol tidak diberikan perlakuan tersebut. Sehingga menyebabkan kemampuan menjelaskan / menginterprestasikan hasil pada kelas eksperiemen lebih baik daripada kelas kontrol.

Berdasarkan hasil analisis jawaban tes kemampuan pemecahan masalah matematika siswa dari deskripsi tiap-tiap indikator yang dipilih maka diperoleh hasil bahwa kemampuan pemecahan masalah matematika kelas eksperimen lebih tinggi daripada kemampuan Pemecahan Masalah Matematika kelas kontrol. Hal ini juga sesuai dengan hipotesis pada penelitian ini, yaitu "Kemampuan pemecahan masalah matematika siswa dengan menggunakan Strategi Pembelajaran Kolaboratif Fishbowl lebih baik dari pada kemampuan pemecahan masalah matematika siswa dengan menggunakan pembelajaran konvensional pada kelas VII SMP Negeri 6 Rengat".

\section{KESIMPULAN DAN SARAN}

Berdasarkan hasil penelitian yang telah dilaksanakan dapat disimpulkan bahwa Kemampuan Pemecahan Masalah Matematika Siswa dengan menggunakan strategi pembelajaran kolaboratif fishbowl lebih baik dari pada kemampuan pemecahan masalah matematika siswa dengan menggunakan pembelajaran konvensional pada kelas VII SMP Negeri 6 Rengat.

Adapun saran dalam penelitian ini adalah Diharapkan pada guru-guru matematika agar dapat menggunakan strategi pembelajaran Kolaboratif Fishbowl sebagai salah satu strategi pembelajaran yang dapat meningkatkan kemampuan pemecahan masalah matematika siswa.

\section{DAFTAR PUSTAKA}

Barkley, Elizabert E. 2012. Collaborative Learning Techniques, Bandung: Nusa Media.

Depdiknas. 2006. Permendiknas No 22 Tahun 2006 Tentang Standar Isi. Jakarta: Depdiknas.

Hamzah, Ali. 2014. Perencanaan dan Strategi Pembelajaran Matematika, Jakarta: Grafindo Persada. 
Ngalimun. 2015. Strategi dan Model Pembelajaran, Banjarmasin: Aswaja Perindo. Rusman. 2015. Model-Model Pembelajaran, Jakarta: PT Raja Grafindo Persada. Sanjaya, Wina. 2006. Strategi Pembelajaran, Jakarta: Kencana Prenada Media Group. Siagian, M.D. 2017. Pembelajaran Matematika dalam Persfektif Konstruktivisme. NIZHAMIYAH (Jurnal Pendidikan Islam dan Teknologi Pendidikan). VII(2). $61-73$

Trianto, 2009. Mendesain model pembelajaran inovatif progresif, Jakarta: kencana perdana.

National Council of Teacher of Mathematics (NCTM). 2000. Principles and Standars for School Mathematics. Reston, VA: NCTM.

Polya, G. 1973. How to Solve It: a New Aspect of Mathematics Method 2nd Edition. New Jearsey: Princeton University Press. 